\title{
SUCCINYLCHOLINE-INDUCED BRADYCARDIA WITH REFERENCE TO METHOXYFLURANE ANAESTHESIA
}

\author{
J. W. R. McInTyre, F.F.A.R.C.S., D.A.*
}

SinCE THE INTRODUCTION of succinylcholine to clinical anaesthesia intravenous injection of the drug in 2 per cent solution has been widely practised. Severe bradycardia and arrhythmias are sometimes produced by single or repeated injections and have been described when the drug has been used with most common anaesthetic agents: thiopentone, nitrous oxide, and oxygen, ${ }^{1-\bar{s}}$ trichlorethylene, ${ }^{3,6}$ cyclopropane, ${ }^{6-9}$ ether, ${ }^{7,8,6}$ halothane, ${ }^{6}$ nitrous oxide meperidine, ${ }^{4}$ nitrous oxide alphaprodine. ${ }^{8}$ The incidence of these disturbances must be small, however, because only few cases of cardiovascular collapse under these conditions are recorded, ${ }^{2,3.5}$ though doubtless others have occurred. The purpose of this paper is to discuss the circumstances under which succinylcholine bradycardia, and arrhythmia appear during induction of anaesthesia with methoxyflurane.

\section{Method}

All patients were adolescents or adults suffering from no cardiac or electroly te disturbances. Morphine or meperidine, and atropine or hyoscine, were administered as premedication. After induction of anaesthesia with thiopentone (one patient received none) the patients were artificially ventilated with a mixture containing $2 \mathrm{~L}$. per minute nitrous oxide and oxygen and approximately 1.3 per cent methoxyflurane into a semi-closed circle absorber system. The patients were arbitrarily divided into three groups, and 2 c.c. 2 per cent succinylcholine given to them according to different sequences: (1) immediately following the thiopentone and four minutes later; (2) four and eight minutes after the thiopentone; (3) eight and twelve minutes after the thiopentone. A fourth group was added in which the succinylcholine was administered according to sequence 2 but in which a second injection of thiopentone, one-third the induction dose, was also made immediately preceding the administration of the repeat dose of succinylcholine. All injections were made rapidly into an antecubital vein. E.C.G. monitoring was done before and for a minute after each injection. The pulse rate was calculated from the maximum $R-R$ interval occurring, and these investigations were completed prior to surgery.

\section{RESULTS}

These are presented in Tables I to IV. Bradycardia did not occur when the succinylcholine (SDC) was given immediately-after the induction dose of thiopentone (cf. Table I). It occurred sometimes when the first dose was given four or eight minutes after the thiopentone (cf. Tables II, III, and IV) and was sometimes preceded by a brief and small increase in pulse rate. Bradycardia occasionally

*Department of Anaesthesia, University of Alberta Hospital Edmonton, Alberta.

Can. Anaes. Soc. J., vol. 9, no. 5, September, 1962 
occurred when the repeat dose was given four minutes after induction (cf. Table I) but was more frequent and severe after the eight and twelve minute repeat doses (cf. Tables II and III). Arrhythmias consisting of $\mathrm{P}$ wave disturbances and auricular and ventricular conduction defects occurred only after repeat doses at eight and twelve minutes after induction. Artificial ventilation had no demonstrable effect on these changes.

A second dose of thiopentone given prior to the repeat injection of SDC at eight minutes produced a significant decrease in the incidence of jradycardia and arrhythmia (cf. Table IV).

TABLE I

Group 1

\begin{tabular}{|c|c|c|c|c|c|c|c|c|c|c|}
\hline $\begin{array}{l}\text { Weight, lb. } \\
\text { (age, yr.) }\end{array}$ & $\begin{array}{l}\text { Pre- } \\
\text { medication, } \\
\text { mg. }\end{array}$ & $\begin{array}{c}\text { Thio- } \\
\text { pentone, } \\
\text { mg. }\end{array}$ & $\begin{array}{l}\text { P.R., } \\
\text { per } \\
\text { min. }\end{array}$ & $\begin{array}{c}\text { SDC, } \\
\text { mg. }\end{array}$ & $\begin{array}{l}\text { P.R., } \\
\text { per } \\
\text { min. }\end{array}$ & $\begin{array}{c}\% \\
\text { change }\end{array}$ & $\begin{array}{l}\text { P.R., } \\
\text { per } \\
\text { min. }\end{array}$ & $\begin{array}{l}\text { SDC, } \\
\text { mg. }\end{array}$ & $\begin{array}{l}\text { P.R., } \\
\text { per } \\
\text { min. }\end{array}$ & $\begin{array}{c}\% \\
\text { change }\end{array}$ \\
\hline \multirow{8}{*}{$\begin{array}{c}117 \\
(50) \\
116 \\
(40) \\
130 \\
(86) \\
170 \\
(29) \\
174 \\
(64) \\
140 \\
(57) \\
98 \\
(26) \\
122 \\
(16)\end{array}$} & \multirow{8}{*}{$\begin{array}{l}\text { D, } 75 \\
\text { A, } 06 \\
\text { D, } 75 \\
\text { H, } 0.4 \\
\text { D, } 50 \\
\text { A, 0.6 } \\
\text { M, } 10 \\
\text { H, 0.4 } \\
\text { D, } 100 \\
\text { A, } 0.6 \\
\text { D, } 100 \\
\text { A, } 0.6 \\
\text { D, } 100 \\
\text { A, } 06 \\
\text { M, } 5 \\
\text { A, } 0.6\end{array}$} & 200 & 94 & \multirow{2}{*}{$8 \begin{array}{r}40 \\
40\end{array}$} & 100 & +6 & 100 & 40 & 100 & 0 \\
\hline & & 300 & 83 & & 94 & +13 & 88 & 40 & 83 & -6 \\
\hline & & 200 & 83 & 40 & 83 & 0 & 88 & 40 & 88 & 0 \\
\hline & & 500 & 68 & 40 & 83 & +22 & 75 & 40 & 75 & 0 \\
\hline & & 300 & 92 & 40 & 92 & 0 & 75 & 10 & 75 & 0 \\
\hline & & 240 & 106 & 40 & 106 & 0 & 106 & 40 & 106 & 0 \\
\hline & & 300 & 115 & 40 & 115 & 0 & 94 & 40 & 62 & -34 \\
\hline & & 400 & 94 & 40 & 100 & +6 & 100 & 40 & 75 & -25 \\
\hline
\end{tabular}

Ndre: $M$, morphine; $D$, meperidine $-H$, hyoscine; $A$, atropine; $S D C$, succinylcholine.

TABLE II

Grout 2

\begin{tabular}{|c|c|c|c|c|c|c|c|c|c|c|}
\hline $\begin{array}{l}\text { Weight, lb. } \\
\text { (age, yr.) }\end{array}$ & $\begin{array}{l}\text { Pre- } \\
\text { medication, } \\
\text { mg. }\end{array}$ & $\begin{array}{l}\text { Thio- } \\
\text { pentone, } \\
\text { mg. }\end{array}$ & $\begin{array}{l}\text { P.R., } \\
\text { per } \\
\text { min. }\end{array}$ & $\begin{array}{c}\text { SDC, } \\
\text { mg. }\end{array}$ & $\begin{array}{l}\text { P.R., } \\
\text { per } \\
\text { min. }\end{array}$ & $\begin{array}{c}\% \\
\text { change }\end{array}$ & $\begin{array}{l}\text { P.R., } \\
\text { per } \\
\text { min. }\end{array}$ & $\begin{array}{c}\text { SDC, } \\
\text { mg. }\end{array}$ & $\begin{array}{l}\text { P.R., } \\
\text { per } \\
\text { min. }\end{array}$ & $\begin{array}{c}\% \\
\text { change }\end{array}$ \\
\hline \multirow{8}{*}{$\begin{array}{c}130 \\
(80) \\
120 \\
(29) \\
140 \\
(50) \\
77 \\
(15) \\
120 \\
(24) \\
140 \\
(19) \\
115 \\
(43) \\
115 \\
(17)\end{array}$} & $\begin{array}{l}D, 100 \\
A, 0.6\end{array}$ & 200 & 83 & 40 & 83 & 0 & 75 & 40 & 75 & 0 \\
\hline & $\begin{array}{l}D, 100 \\
A, 0.6\end{array}$ & 600 & 75 & 40 & 79 & +5 & 83 & 40 & 62 & -25 \\
\hline & & 400 & 83 & 40 & 83 & 0 & 75 & 40 & $48^{*}$ & -36 \\
\hline & $\begin{array}{l}D, 100 \\
A, 0.6\end{array}$ & 300 & 115 & 40 & 115 & 0 & 107 & 40 & $58^{*}$ & -46 \\
\hline & $\begin{array}{l}\mathrm{D}, 100 \\
\mathrm{H}, 0.4\end{array}$ & 400 & 100 & 40 & 88 & -12 & 83 & 40 & $44^{*}$ & -47 \\
\hline & $\mathrm{H}, 0,4$ & Nil & 68 & 40 & 62 & -9 & 71 & 40 & $11^{*}$ & -85 \\
\hline & $\begin{array}{l}\mathrm{A}, 0.6 \\
\mathrm{M} 8\end{array}$ & 400 & 106 & 40 & 88 & -17 & 115 & 40 & 75 & -35 \\
\hline & $\mathrm{H}, 0.4$ & 400 & 80 & 40 & 70 & -13 & 72 & 40 & $46^{*}$ & -36 \\
\hline
\end{tabular}

${ }^{*} \mathrm{~A}-\mathrm{V}$ nodal rhythm. 
TABLE III

Group 3

\begin{tabular}{|c|c|c|c|c|c|c|c|c|c|c|}
\hline $\begin{array}{c}\text { Weight, lb. } \\
\text { (age, yr.) }\end{array}$ & $\begin{array}{l}\text { Pre- } \\
\text { medication, } \\
\text { mg. }\end{array}$ & $\begin{array}{c}\text { Thio- } \\
\text { pentone, } \\
\text { mig }\end{array}$ & $\begin{array}{c}\text { P.R., } \\
\text { per } \\
\text { min. }\end{array}$ & $\begin{array}{c}\text { SDC, } \\
\text { mg. }\end{array}$ & $\begin{array}{c}\text { P.R, } \\
\text { per } \\
\text { min. }\end{array}$ & $\begin{array}{c}7 \% \\
\text { change }\end{array}$ & $\begin{array}{l}\text { P.R., } \\
\text { per } \\
\text { min. }\end{array}$ & $\begin{array}{c}\text { SDC, } \\
\text { mg. }\end{array}$ & $\begin{array}{c}\text { P.R., } \\
\text { per } \\
\text { min. }\end{array}$ & $\begin{array}{c}\% \\
\text { change }\end{array}$ \\
\hline \multirow{8}{*}{$\begin{array}{l}171 \\
(68) \\
126 \\
(38) \\
157 \\
(48) \\
185 \\
(52) \\
170 \\
(53) \\
180 \\
(37) \\
135 \\
(45) \\
120 \\
(16)\end{array}$} & $\begin{array}{l}\mathrm{D}, 100 \\
\mathrm{H}, 06\end{array}$ & 300 & 62 & 40 & 65 & $+t$ & 65 & 40 & 60 & -8 \\
\hline & $\begin{array}{l}\text { A, } 06 \\
\mathrm{MI}, 15\end{array}$ & 340 & 88 & 40 & 75 & -15 & 79 & 40 & 65 & -18 \\
\hline & $\begin{array}{l}\text { A, } 06 \\
\text { II } 10\end{array}$ & 500 & 94 & 40 & 88 & -6 & $9 !$ & 40 & 68 & -28 \\
\hline & $\begin{array}{l}\mathrm{H}, 04 \\
\mathrm{D}, 100\end{array}$ & 500 & 94 & 40 & 94 & 0 & 100 & 40 & 43 & $-57^{*}$ \\
\hline & $\begin{array}{l}\mathrm{H}, 04 \\
\mathrm{D}, 100\end{array}$ & 500 & 79 & 40 & 79 & (1) & 75 & 40 & 79 & 5 \\
\hline & $\begin{array}{l}\mathrm{H}, 04 \\
\mathrm{D}, 100\end{array}$ & $\left.18^{1}\right]$ & 115 & 40 & 115 & 1) & 106 & 10 & 62 & -42 \\
\hline & $\begin{array}{l}\text { A, } 06 \\
\text { D, } 100\end{array}$ & 400 & 80 & 40 & 92 & +15 & 92 & 40 & 64 & -30 \\
\hline & A, 06 & 400 & 86 & 40 & 89 & +2 & 81 & 40 & 56 & -33 \\
\hline
\end{tabular}

TABLE IV

Group 4

\begin{tabular}{|c|c|c|c|c|c|c|c|c|c|c|}
\hline $\begin{array}{c}\text { Weight, lb } \\
(\text { age, yr) }\end{array}$ & $\begin{array}{c}\text { Pre- } \\
\text { medication, } \\
\text { mg. }\end{array}$ & $\begin{array}{l}\text { Thio- } \\
\text { pentone, } \\
\text { mg }\end{array}$ & $\begin{array}{l}\text { P.R., } \\
\text { per } \\
\text { min. }\end{array}$ & $\begin{array}{l}\text { SDC, } \\
\text { mg. }\end{array}$ & $\begin{array}{l}\text { P.R., } \\
\text { per } \\
\text { min }\end{array}$ & $\begin{array}{c}c / c \\
\text { change }\end{array}$ & $\begin{array}{l}\text { PR., } \\
\text { per } \\
\text { mun }\end{array}$ & $\begin{array}{l}\mathrm{SDC}, \\
\mathrm{mg}\end{array}$ & $\begin{array}{l}\text { P.R., } \\
\text { per } \\
\text { min. }\end{array}$ & chànge \\
\hline \multirow{9}{*}{$\begin{array}{l}124 \\
(49) \\
174 \\
(26) \\
160 \\
(18) \\
180 \\
(55) \\
140 \\
(29) \\
157 \\
(50) \\
123 \\
(20) \\
135 \\
(51)\end{array}$} & \multirow{9}{*}{$\begin{array}{l}\text { D, } 75 \\
\text { H, } 06 \\
\text { M, } 15 \\
H, 06 \\
\text { D, } 100 \\
\text { A, } 06 \\
\text { A, } 15 \\
\text { A, } 06 \\
\text { M, } 10 \\
\text { A, } 06 \\
\text { M, } 10 \\
\text { H, } 04 \\
\text { M, } 10 \\
\text { H, } 04 \\
D, 75 \\
\text { A, } 06\end{array}$} & 400 & 83 & 40 & 83 & 0 & 79 & \multirow{9}{*}{$\begin{array}{l}135 \\
(40) \\
200 \\
(40) \\
200 \\
(40) \\
100 \\
(40) \\
130 \\
(40) \\
100 \\
(40) \\
80 \\
(40) \\
130 \\
(10)\end{array}$} & 79 & 0 \\
\hline & & 600 & 94 & 40 & 65 & $-31_{2}$ & 100 & & 100 & 0 \\
\hline & & 600 & 80 & 40 & 88 & +10 & 92 & & 100 & +9 \\
\hline & & & & & & & & & & \\
\hline & & 500 & 94 & 40 & 100 & +6 & 88 & & 88 & 0 \\
\hline & & 400 & 88 & 40 & 88 & 0 & 75 & & 75 & 0 \\
\hline & & 300 & 56 & 40 & $5 ;$ & () & 65 & & 79 & +21 \\
\hline & & 240 & 65 & 40 & 71 & +9 & 62 & & 75 & +21 \\
\hline & & 400 & 88 & 40 & 88 & 0 & 8.3 & & 88 & +6 \\
\hline
\end{tabular}

\section{Discussion}

Williams $e t a l .$, using succinylcholine with a variety of drugs in man, concluded that the cardiac changes were mediated via sympathetic and parasympathetic efferent nerves. ${ }^{6}$ Galindo and Davis explained the changes on the basis of si npathetic post-ganglionic stimulation producing reflex cardiac effects via the baroreceptors and vagus nerve, ${ }^{10}$ thus confirming in monkeys the observations of Beretervide in dogs and rabbits. ${ }^{11}$ The latter worked with conscious animals and noted that anaesthesia with pentobarbitone abolished the response. The effectiveness of thiopentone in preventing a response to centrally induced arrhythmias in cats has been demonstrated by Purpura. ${ }^{12}$ The results presented 
here show the effectiveness of thiopentone in depressing this response to succinylcholine, and it is noteworthy that though this complication has been described with most anaesthetic agents, in a group of six cases anaesthetized with thiopentone intermittently or by continuous drip, severe bradycardia did not occur after either injection, and arrhythmia occurred in only one instance. ${ }^{6}$ Thiopentone injections undergo rapid redistribution within the body and this may account for the inability of the induction dose of thiopentone to provide more than a brief protection. Lupprian and Churchill-Davidson mention further doses of thiopentone given during nitrous oxide - oxygen anaesthesia to satisfy anaesthetic requirements for their investigation ${ }^{4}$ but give no other details. Johnstone followed a "small dose" of thiopentone with succinylcholine $60 \mathrm{mg}$. after a delay of one minute. ${ }^{2}$ The fact that both could elicit bradycardia and arrhythmias can be explained by the dosage of thiopentone used and its time of administration relative to that of the succinylcholine.

If thiopentone can reduce the response it might be supposed that the depth ot anaesthesia influences this effect of succinylcholine. ${ }^{7,6}$ No attempts have been made to utilize E.E.G. recording for a study of this, but in the series presented the depth of anaesthesia at which severe bradycardia occurred was indistinguishable clinically from that at which it failed to occur. A safe correlation between the transient increase in pulse rate and the occurrence of bradycardia subsequently could not be established. The concentration of methoxyflurane used was small, but the difference in the incidence of arrhythmia at the eight and twelve minute periods may indicate a raised threshold due to deeper anaesthesia.

The majority of early reports of this phenomenon describe its bccurrence after a single dose, ${ }^{2,7,8,9.1}$ but more recently attention has been drawn to accentuated changes after a repeat dose. These changes may be: irrespective of the size of the dose ${ }^{3}$ or dependent on it ${ }^{6}$; unrelated to the initial dose but related to the repeat dose, which must exceed $25 \mathrm{mg}^{4}$; limited to the second and third dose ${ }^{3}$ or unlimited to the number of doses $^{6}$; inversely related to the length of time between injections. ${ }^{6}$ The complete mechanism of production of succinylcholine-induced bradycardia and arrhythmia has not been elucidated, but these variable effects may be explained by the ratio of vagomimetic to sympathomimetic activity of the anaesthetic drugs used, and the thiopentone level in the blood.

Intravenous atropine will reverse an established bradycardia of this origin, ${ }^{2} 7116$ but its use intramuscularly as premedication in this series confirms the very modest protective effect of the drug when used in this manner.6.4 92 Morton and Thomas have studied the effect of atropine on the pulse rate and stress the importance of administering a substantial dose intravenously to avoid the vagomimetic effects of the drug. ${ }^{13}$ The intravenous administration of $0.4 \mathrm{mg}$. atropine during halothane anaesthesia in man has produced evidence of vagal stimulation..$^{15}$ For prophylactic purposes, prior to the succinylcholine, a dosage of at least 0.6-1.0 mg. has been advocated ${ }^{5}{ }^{4}$ with a delay until a tachycardia has ensued. Atropine considerably increases myocardial sensitivity to carbon dioxide retention during halothane anaesthesia, and under these circumstances ventricular arrhythmias may occur. ${ }^{14}$ In view of the fact that an increase in myocardial excitability due to succinylcholine has been demonstrated in monkeys under halothane 
anaesthesia and these responses will be influenced by potassium concentrations and other factors, ${ }^{10}$ the use of atropine, while providing protection against reflex bradycardia and arrhythmias, may sometimes introduce other hazards to cardiac function during halothane and possibly methoxyflurane anaesthesia.

\section{Conclusion}

The administration of succinylcholine 2 per cent when thiopentone is omitted for induction, or when it is used in minimal doses not immediately preceding the injection of the relaxant, should be done with caution. The hazard is very small except in patients suffering from cardiac dysfunction or electrolyte disturbances. A further dose of succinylcholine markedly increases the danger unless prophylactic measures are taken, and a larger dose initially may have a similar effect.

The anaesthesia sequence producing the most marked bradycardia and arrhythmias is unusual in clinical practice and when it is used additional thiopentone is often given. These facts probably account for the low incidence of serious complications of this nature.

\section{SUMmari}

Healthy adolescent or adult patients were premedicated with morphine or meperidine, and atropine or hyoscine, and anaesthetızed with a sequence thiopentone, nitrous oxide, oxygen, methoxyflurane. Thœy were arbitrarily divided into three groups and intravenous injections of 2 c.c 2 per cent succinylcholine given according to three different sequences: (1) immediately following the thiopentone and four minutes later; (2) four and eight minutes after the thiopentone, (3) eight and twelve minutes after the thiopentone. A fourth group was added, for which a sequence similar to sequence 2 was used except that, prior to the second injection of succinylcholine, a second injection of thiopentone, one-third of the amount used for induction, was given.

The existing reports of succinylcholine-induced bradycardia and arrhythmias are discussed with reference to the results. The conclusions reached are that the administration of succinylcholine 2 per cent when thiopentone is omitted for induction, or used in minimal dosage not immediately preceding the injection of the relaxant, should be done with caution. The hazard is very small except in those patients suffering from cardiac dysfunction or electrolyte disturbances. A further dose of succinylcholine markedly increases the danger unless prophylactic measures are taken, and a larger dose initially may have a similar effect.

The anaesthesia sequence producing the most marked bradycardia and arrhythmia is unusual in clinical practice and when it is used additional thiopentone is often given. These facts probablv account for the low incidence of serious complications of this nature.

\section{RÉSUMÉ}

Nous avons prémédiqué des adolescents ou adultes en santé avec de la morphine ou du démérol, et de l'atropine ou de l'hyoscine, et nous les avons anesthésiés avec du thiopentone du protoxyde d'azote, de l'oxygène et du méthoxyflurane. De façon arbitraire, nous les avons divisés en trois groupes et des injections intraveineuses de $2 \mathrm{ml}$. à 2 pour cent de succinylcholine leur ont été données de trois 
façons différentes: (1) une injection immédiatement après le thiopentone et l'autre quatre minutes plus tard; (2) quatre et huit minutes apròs le thiopentone; (3) huit et douze minutes après le thiopentone. Nous avons fait un quatrième groupe semblable au deuxième à l'exception que, avant la seconde injection de succinylcholine, une seconde injection de thiopentone était donnée représentant le tiers de la dose donnée pour l'induction.

Les bradycardies et les arythmies provoquées par la succinylcholine qu'on trouve dans la littérature sont discutées selon les résultats mentionnés. Nous en venons aux conclusions qu'il faut agir avec prudence lorsqu'on administre de la succinylcholine à 2 pour cent si l'on omet de donner du thiopentone pour l'induction ou que l'on en injecte très peu, ou que l'injection de thiopentone ne précède pas immédiatement le myorésolutif. Le risque est très petit, excepté pour les malades porteurs de dysfonction cardiaque ou de déséquilibres électrolytiques. Une deuxième dose de succinylcholine aggrave beaucoup le danger à moins que des mesures prophylactiques soient prises, et une plus grosse dose initiale peut produire un effet semblable.

Le mélange anesthésique produisant le plus de bradycardie et d'arythmies n'est pas habituel en clinique et, lorsqu'il est employé, on ajoute du thiopentone. Ces faits expliquent probablement pourquoi des complications sérieuses de cette nature ne surviennent pas souvent.

\section{REFERENCES}

1. Barreto, R. S. Effect of Intravenous Administration of Succinylcholine on Cardiac Rate and Rhythm. Anesthesiology 21: 401 (1960).

2 Johrstone, M. Relaxants and the Human Cardiovascular System Anaesthesia 10: 122 (1955).

3. Bullovgh, J. Correspondence. Brit. Med. J. i: 786 (1959).

4. Lupprian, K. G. \& Churchill-Davidson, H. C. Effect of Suxamethonium on Cardiac Rhythm. Brit. Med. J. ii: 1774 (1960).

5. Verner, I. \& CoMty, C. Correspondence. Brit. Med. J. i: 1239 (1959).

6. Williams, C. H.; Deutsch, S.; Linde, H. W.; Bullough, J. W.; \& DRipps, R. D. Effects of Intravenously Administered Succinyldicholine on Cardiac Rate Rhythm and Arteria! Pressure in Anaesthetised Man. Anesthesiology 22: 947 (1961).

7. Craythorne, N. W. B.; Turndorf, H.; \& Dripps, R. D. Changes in Pulse Rate and Rhythm Associated with the Use of Succinylcholine in Anesthetised Children. Anesthesiology 21: 465 (1960).

8. Leigh, M. Digby; McCoy, D. D.; Belton, M. K.; \& Lewis, G. B. Bradycardia Following Intravenous Administration of Succinylcholine Chloride to Infants and Children. Anesthesiology 18: 698 (1957).

9. Telford, J. \& Kears, A. S. Succinylcholine in Cardiovascular Surgery of Infants and Children. Anesthesiology 18:811 (1957).

10. Galindo, Anibal \& Davis, Thomas B. Succinylcholine and Cardiac Excitability. Anesthesiology $23: 33$ (1962).

11. Beretervide, K. V. Action of Succinylcholine on the Circulation. Brit. J. Pharmacol. 10: 265 (1955).

12. Purpura, D. P.; Pool, J. L.; Housepian, E. M.; Girado, M.; Jacobson, S. A.; \& Seymour, R. J. Hypothermic Potentiation of Centrally Induced Cardiac Irregularities. Anesthesiology 19: 27 (1958).

13. Morton, H. J. V. \& Thomas, E. T. Effect of Atropine on the Heart Rate. Lancet ii: 1313 (1958).

14. Johnstone, M. \& Nisbet, H. I. A. Ventricular Arrhythmias during Halothane Anaesthesia. Brit. J. Anaes. 33: 9 (1961).

15. Jones, R. E.; Deutsch, S.; Turndorf, H. Effects of Atropine on Cardiac Rhythm in Conscious and Anesthetised Man. Anesthesiology 22: 67 (1961). 